\title{
Infrastructure Development: China's Investment Aid and Subsidy Projects in Africa: Case of the Central African Republic
}

\author{
Debongo Devincy Yanne Sylvaire* ㅌ), Traoré Fatoumata, Umutoniwase Marie Aimée \\ School of Management, Hefei University of Technology, Hefei, China \\ Email: ^bongoven@yahoo.fr, fatimtraore9@gmail.com, umutoni56@gmail.com
}

How to cite this paper: Sylvaire, D. D. Y., Fatoumata, T., \& Aimée, U. M. (2020). Infrastructure Development: China's Investment Aid and Subsidy Projects in Africa: Case of the Central African Republic. American Journal of Industrial and Business Management, 10, 1870-1885. https://doi.org/10.4236/ajibm.2020.1012117

Received: November 19, 2020 Accepted: December 28, 2020

Published: December 31, 2020

Copyright $\odot 2020$ by author(s) and Scientific Research Publishing Inc. This work is licensed under the Creative Commons Attribution International License (CC BY 4.0).

http://creativecommons.org/licenses/by/4.0/

\begin{abstract}
China's investment aid has a significantly positive impact on Africa's continent economic growth, development, and social life. China's subsidized various projects under the bilateral cooperation between the China-Africa relationships. For the presentation on these projects, the Chinese government's financing shows us a brief presentation of the objectives and fair contribution of China's investment on successful projects case in the Central African Republic that is the part of the African countries.
\end{abstract}

\section{Keywords}

China-Africa, Sino-Centrafricano, Aid, Investment, Impact, Projects

\section{Introduction}

Over the last 30 years, China plays an essential role in the economic growth and development in sub-Saharan African countries and has become a principal economic partner. The trade between China-Africa increased significantly in 2000 from $\$ 9$ billion to $\$ 166$ billion in 2012, making China Africa the most considerable and suitable trade partner (UN Comtrade, 2014). In terms of China's FDI flows in the African countries, it was increased positively from \$200 in 2000 million to $\$ 2.9$ billion in 2011, making China the second-largest developing country investor after the USA in Africa continent (UNCTAD, 2013). Simultaneously, Chinese aid initiatives in the continent in the economic or technical bilateral cooperation have increased significantly in these recent years. The economic cooperation project in Africa obtained \$29 billion in 2011 compared to $\$ 1.2$ in 2000 estimated by China's National Bureau of Statistic (NBS).

At the same moment, the African country's economic growth has improved 
significantly except for the following negative growth rates in the 1980s and 1990s. Africa's continent Gross Domestic Product (GDP) per capita average growth rates with $1.8 \%$ in 2010-2012 (World Bank, 2014). Seeing the positive impact on China's FDI and aid to the economy and development in these recent years in Africa, China's engagement has contributed positively to the continent's economic growth. Many factors have contributed to the African countries with better growth performance, including market improvement in different institutions and infrastructure, decreasing conflicts, and macroeconomic distortions (OECD et al., 2013). Regarding the excellent Sino-Africano economic relationships that result in the host country's impact, China's aid to African growth seems appropriate and encouraging.

Nevertheless, the Chinese economy has multiplied its Gross Domestic Product (GDP) by 15 to maintain a healthy home economic growth and ensure a constant supply of raw material and energy. Indeed, China turned towards the African continent by quickly and firmly multiplying its foreign direct investments during the last decades (Sautman \& Yan, 2009). By becoming the second-largest business partner of Africa, as well as a strategic investor, a financial supplier, and associated with the development, China has now overturned the balance of powers established since Africa's decolonization (Liu \& Lu, 2013).

In July 2014, the Chinese government released a new white paper on China's foreign aid, the second document in history. Compared to the previous one, published in April 2011, the new white paper focuses on Beijing's general aid policies or its historical practices and the specific priorities and implementation of Chinese current foreign assistance. The white paper also offers more successful and positive concrete examples of agricultural, infrastructure, capacity-building projects in developing countries, and medical assistants for the African countries ( $\mathrm{Su}, 2017)$. From the statistics, overall, China has increased its direct foreign aid efforts since 2009. From 2010 to 2012, China's foreign aid of approximately $\$ 14.9$ billion was equivalent to $35 \%$ of all direct foreign aid China had provided in the previous six decades. China's annual foreign aid with $\$ 5$ billion is lowest than the estimates in a recent report Estimating China's Foreign Aid from 2001 to 2013 by the Japanese International Cooperation Agency Research Institute. The composition of China's aid financing and development has also undergone significant. The sharing of the different types of China's aid financing has changed. For example, concessional loans now make up most of China's aid financing; their share grew from $28.7 \%$ to $55.7 \%$, while zero-interest loans share shrank from $29.8 \%$ to $8.1 \%$, and the share of grants also decreased from $41.4 \%$ to $36.2 \%$.

The majority of Africa's noteworthy point in China's foreign aid is the rising percentage of aid received by the continent. In 2011 China's foreign aid to the African continent in 2009 made up $45.7 \%$ of China's total foreign aid, while, from 2010 to 2012, the share for Africa climbed to 51.8\%. The infrastructure development is defined as the construction and improvement of foundational services to spark economic growth and improve life quality. Infrastructure devel- 
opment can involve any infrastructure, including transportation, energy, water, digital, social, and green infrastructure (Annen, 2003). Thus, aware of this crisis, investors have been reluctant to invest in Africa, subject to periodic ups and downs. However, it is noted that during the last decade, China has been interested the case of the Central African Republic by intervening in different areas or sectors, such as constructing public buildings, roads, engineering structures, petroleum research, and cooperation in the health, educational, cultural, and military fields (Zhang, 2016).

Contrary to the positive impacts of China's FDI and aid, China determination and engagement in the African continent certainly have negative impacts on the African economic growth as well, and, the enormous demand for the raw materials, Africa countries exports are more concentrated in the primary sector such as natural resource (Carmignani \& Chowdhury, 2012). The bilateral exchange rate between China-Africa due to the increasing exportation of natural resources could fit the rent seeking and corruption (Busse \& Gröning, 2013). This frequent situation has pushed most African countries' institutions into a weak position. By its non-interference policy, China could not pay attention to consideration the quality of the governance level in trade, investment, and aid to any necessary reforms.

Regarding the determinants of China's FDI and aid in Africa, Kolstad \& Wiig (2011) find that Chinese FDI flows to Africa are focusing only on natural resources endowments. Besides, Chinese firms in Africa had occupied the most places and became competitors if both produce similar products, and it causes internal conflicts. Both parties of exchange rate overvaluations and low-price competition of goods manufacturing, and by seeing the interest country consideration of the products, mainly to ceramic, furniture, footwear and textiles (Morrissey \& Zgovu, 2011).

This observation of China's renewed attention pushes us to question the Chinese breakthrough opportunities in African countries, including the Central African Republic. To our best knowledge, we could not yet find the exactitude of the impact on China's FDI and aid projects analysis realized by the Chinese government via public or private companies in Africa. To obtain a persuasive argument for all this matter, we identify and analyze the projects carried out by China through Chinese companies implemented in Africa, particularly the case of Central African Republic, and analyze subsidized projects their impact on African countries' economic growth and development. The rest is as follows: In the second part, the illustration of the leading project related by a few literature reviews between China's investment and financing aid in Africa. In the third part, China's financing investment and aid to Africa and mutual support during the pandemic period. The fourth, China's general investment aid donor policy and the impact on economic development in Africa. Furthermore, the fifth, the Case of the Central African Republic. Furthermore, the sixth had a conclusion. 


\section{Literature Review}

This literature review can only illustrate the projects' selection and concise synthesis of critical points between the Sino-Africa relationships. The review has selected the most recent rigorous analysis available and some older and new papers review on China-Africa cooperation. China's expanding global role in Africa and its growing aid or subvention and economic cooperation overseas attract attention and analysis. There is enormous research from policy organizations, academic researches, or various aspects of Chinese aid in Africa and its economic cooperation more and more broadly. This research on China's aid and subvention approaches a country or regional case studies, specifically focusing on aid or single projects or sectors in African countries.

China is the largest and developing country that provides grants and interest-free loans (Ministry of Commerce and concessional loans by China Exim Bank. Most Chinese foreign aid forms are completing projects, goods, materials, technical cooperation; human resources development cooperation, medical teams, and volunteers. China makes a multilateral contribution to the World Bank, IMF, and UN agencies. However, the bilateral cooperation between China and African countries consists of aid or subvention that is large than the multilateral aid. When China provides aid or subvention, it is generally a government to government relationship. China's underdeveloped civil society is rarely used, although China has shown increasing interest in channeling international cooperation funds through civil society organizations. China's development aid and finance go well beyond its traditional aid program, including export buyers' credit, available loans at market rates, and strategic lines of credit provided to Chinese enterprises with the two-state policy banks-China Exim Bank and the China Development Bank playing key roles (Lakatos, 2016). The Chinese government official in 2000 has led to a series of Chinese initiatives such as One Belt and One Road initiative by Chinese President Xi Jinping and the Asian Infrastructure Investment Bank, which along with the BRICKS New Development Bank, imply a new economic, political geography of international development cooperation.

China's capital flowing into Africa also creates business opportunities for Chinese service contractors, such as construction public and private companies. Africa is China's second-largest supplier of service management contracts and is exchanged for more Chinese Financial subvention to African countries. Being required infrastructure construction contracts favor Chinese service providers: $70 \%$ go to approved, and most state-owned Chinese companies are open to local firms. While joint ventures with Chinese groups, and China's financing to the Central African Republic, including aid and subvention, create business and employment profit for Chinese workers. Simultaneously, it also increased the demand for Chinese exports and allowed China's incursion to explore and invest in minerals and forest resources in African countries (Brautigam, 2009).

According to the excellent relationship between China and Africa, China's 
economic and development cooperation since introducing the "Going out" policy, China is now one of the world's ten most considerable development assistance (Bohoslavsky, 2016). China's development assistance is the much larger policy bank lending to developing countries. Much of the research focuses on China's relationship and economic cooperation with Africa. Officially, Chinese statistics state that China appropriated from 2010 to 2012 in total $\$ 14.41$ billion for foreign assistance commitments. China and Africa research initiative (CARI) finds that from 2000 to 2015, the Chinese government, banks to African government and state-owned enterprises (SOEs).

As we all know, China has been involved in overseas health assistance for decades and becomes a significant global player in this sector exactly in Africa. For health aid approach is the absence of a cohesive and coherent strategy of China's health diplomacy (Lin et al., 2016). Besides, China's kept focused on the economic case, including infrastructure financing, infrastructure assistance is a priority for China, the largest sector for commercial and concessional loans to Africa during 2000-2014 was transportation loans for constructions, renovation of roads, railways, airports, and harbors (Hwang et al., 2016). Agricultural development is another priority. Chinese development cooperation in Africa increasingly includes agriculture, agribusiness, contract with farming, technology demonstration, and training. The Chinese government also invested in sociocultural initiatives such as the One Belt and One Road.

Moreover, trilateral assistance is explicitly intended to promote China's image and legitimacy abroad (Shambaugh, 2015; Zhang, 2017). Other sociocultural elements of Chinese assistance to developing countries include training which focuses in part on transferring information about China's own experience with urbanization, economic growth, and poverty alleviation); scholarship for university study in China. The Chinese government has a plan, future trends for China's aid, a broader economic strategy, and most of China's engagement turn in Africa. The impact of Chinese aid like architecture, critical issues for China's involvement in the individual sector, this Chinese impact aid affected most of the international aid system.

\section{China's Financing Investment and Aid to Africa and Mutual Support during the Pandemic Period}

China has an enormous bilateral aid program, but it has also helped create alternative multilateral funding sources for developing African. Globally, the development landscape is currently in a period of tumult, the majority of developing countries that were once aid recipients are donors, and they represented a growing part of the total money spent on international development for Africa (Sun, 2014). China is the largest emerging competitor in the global aid market, and its unique way of designing and delivering assistance in Africa. Chinese government departments and agencies fund nearly 2650 development projects in 54 African countries worth approximately $\$ 198$ billion (China Yearbook). Chi- 
na-Africa cooperation started because the continent receives more than half of China's international development budget each year. Its attitude towards aid transparency norms is a case in point. China has opted out of global reporting systems, such as the International Aid Transparency Initiative (IATI), which Western countries put in place to facilitate donor coordination and minimize duplication and waste. Instead, Beijing has chosen to release few details about its rapidly growing international development finance program, making China's foreign aid program an informational black hole.

The world economic trade and investment were declined, causes by new pneumonia provoked by the novel coronavirus at the beginning of the year 2020 . And, this outbreak not only affects and damages Chinese domestic economy and trade, but also causes huge losses to the African countries' domestic economy and trade and the whole world. According to the new initiative of Chinese president Xi Jinping, "One Belt and One Road", Chinese government assists positively African countries by giving donors of different products. We have as an example Alibaba Foundation, Diasia Biochemical Technology Co., Ltd, Jig Brand Management (Shanghai) Co., Ltd. and Anhui Lianfei Business Consultant Information Co., Ltd. In Figure 1, we can find all those products such as disposable medical mask, children's hygiene mask, coronavirus rapid testing kits. Also, children garment, children school bags, children shoes that can help 54 African countries official government against the virus and to have a healthier social life. All these donations were under supervision of the Chinese government.

Besides, many African countries sent the contribution and the message of comfort to China during their hardship time. First, moral support is provided through telephone declaration and subsequent medical supplies, such as masks and gloves. Equatorial Guinea donated a sum of roughly $\$ 1.77$ million to aid China in its fight against the coronavirus outbreak. At the same moment, the poorest Union of the Comoros, an island nation in the Indian Ocean, an association lead by Dr. Ahamada Msa M'liva has given China a symbolic gift donation of $\$ 120$ to help in the fight against the pandemic called "coronavirus". A few countries contributed, such as Burundi, Cameroon, Cape Verde, Egypt, Eritrea, Ivory Coast (Africa voice media, Wikipedia 2020). Besides, the scholars who are studying China's contributions have made so many contributions during the pandemic, and it is just a few of what they have done. A group of African students in China volunteered during the covid-19 pandemic in different cities in China. Some African students from Uganda were volunteering to take temperature and giving masks at the subway stations and delivered foods given by the university authorities in Wuhan city. Some African students from South Africa and Mauritius volunteered at the hospitals in Wenzhou city, China. A group of other African students' volunteers to take temperature and advise how to prevent the covid-19, shared dishes are given by the different universities in Anhui province. Simultaneously, some African students from Zimbabwe were also volunteering at the rail station, taking temperature, and helping people carry their 


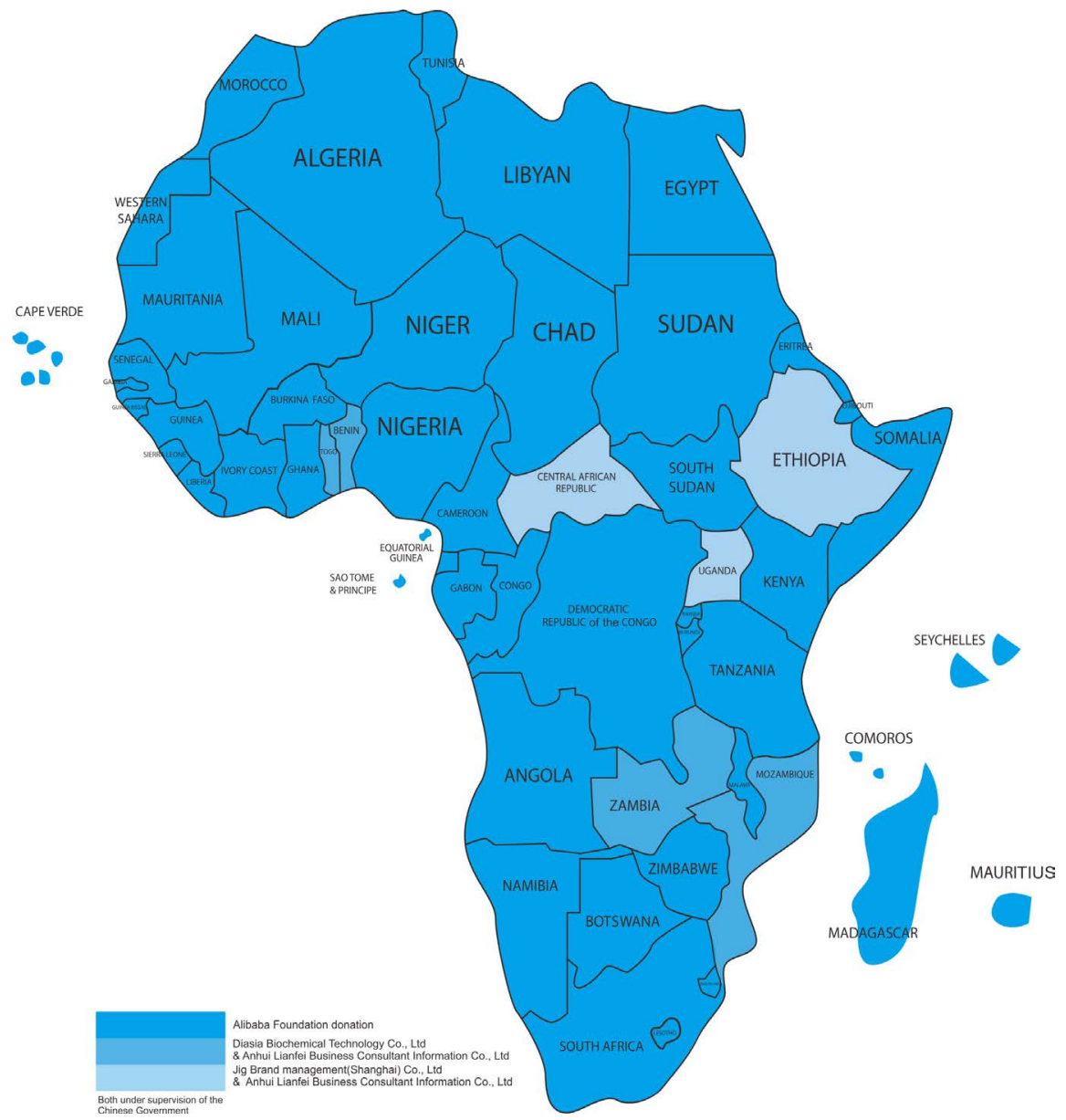

Figure 1. African countries received donates. Source: CCTV News. Alibaba Foundation. Diasia Biochemical Technology Co., Ltd. Jig Band Management (Shanghai) Co., Ltd. Anhui Lianfei Business Consultant Information Co., Ltd.

luggage in Hangzhou city. They were also organized by African students in China to help fight the pandemic, like organizing the awareness shows. They composed a song that joined students from different African countries called "we are together" to show love to those working on the front line and comfort the families who lost their beloved. They also wrote letters to the doctors, nurses, and police to appreciate their effort and encourage them about the excellent work.

In sum, China-Africa supported mutually during the pandemic crisis in a different way to prove their perfect relationships, and this relationship has to continue forever.

\section{China's General Investment Aid Donor Policy and the Impact on Economic Development in Africa}

China's foreign aid in Africa underwent major reforms between 2006 and 2015 and affected 3 main points that we have to show them up. First it the new instruments that linked aid, trade, and investment between China-Africa that were introduced and implemented in these recent decades. The second is concentrated in the program that combined foreign aid with economic cooperation de- 
veloped and financed. And the third, China refined its portfolio of tools to aid domestic restructuring. The restructuring also showed the creation of 3 policy banks in Africa. China's development Bank, China Export-Import bank, and China Agricultural Development bank, all state-owned and enabled the government to provide targeted financing and aid. The new policy opened the perspective of economic growth and trade strategies between China-Africa bilateral cooperation. Chinese direct foreign investments in manufacturing and agriculture and growth in most Chinese assembly factories in Africa created a new employment area for African citizens.

China's aid to Africa covers a wide array of fields, such as agriculture, education, transportation, energy, communications, and health. According to Chinese scholars and authors, since 2003, China has provided almost 1000 aid projects to African countries, including assistance supporting textile factories, hydropower stations, stadiums, hospitals, and schools.

\subsection{Impact of China's Aid, Trade and Investment in Africa}

According to the several projects realized and subdivided via aid, trade, and investment in Africa, we realized two points that contribute positively to African countries. First, it has a potentially positive impact on the host country and immensely beneficial for the local citizen. They appreciated it because it helps and plays a vital role in economic growth and development by creating new jobs and improving the local income. From this new initiative of aid, trade, and investment, most African countries' government officials established social security and reduced the highest level of poverty. Second, those projects may be boosted and increased local economic activity and promoting sustainable economic and social development.

\subsection{Impact of China's Foreign Aid and Economic Cooperation}

Generally, China is the largest investor in Africa in terms of capital and bilateral economic cooperation. It shows real engagement to China in Africa by giving foreign aid that could keep the high level of Africa's economic growth and development opportunities. China's foreign aid has a substantial impact on Africa's economy and development. Most government officials appreciated even corporate to make economic cooperation fruitfully by exchanging new methods or energy transfer that is profitable for most African countries. Example of solar venture finance as an aid under the bilateral cooperation invested in training local engineers and technicians on the new transfer technologies to expand solar capacity, which benefits Kenya's economic and development growth. The same example of Nagad railway station built and finance by China in Djibouti reduced the unemployment rate of the youth and promoted the increase of wages.

\subsection{Impact on Domestic Aspect}

Fortunately, 54 African countries have improved their domestic aspect under China's aid in the continent. Many infrastructure projects were supported and 
continue to support by China assistance aid by building hospitals, schools, bridges, roads, and railways that are profitable and contributing to the local economy and development in Africa. Chinese factories in Africa are also overwhelming the native producers with an enormous volume of cheapest goods. The majority of Chinese companies in Africa are welcome. All the African workers who are employed have happy and enjoy their jobs because it helps them have a remarkable social life and contributes to the local economic environment. For example, there is a textiles factory in Ethiopia named (Fu Jiang) that contributed positively to the local economic growth, and most Ethiopian workers appreciate it.

Indeed, China's aid assistance to Africa is beneficial and appreciated by African citizens. Nevertheless, it also harms the African continent, and we have to reassess this issue. Chinese aid assistance and investment are sectoral, and China has another view that most African nations did not see. All the aid, trade, and investment are not free. Africa has vast natural resources, so China uses its aid assistance in exchange for natural resources. For example, in Angola, Equatorial Guinea, and the Central African Republic, China is the one to explore oil and other natural resources such as diamonds, gold, lead zinc, platinum, uranium. China's aid assistance and investment cause internal conflicts, the highest level of corruption and nepotism. At the same, most Chinese factories implant in Africa is the source of environmental destruction such as water and air pollution. Many rare species disappear due to the noise of the machines used by Chinese enterprises-for example, the refineries of the Angolan and Equatorial Guinea oil companies.

In sum, China's aid contributed positively to Africa's economic development differently, and most of the contributions are beneficial and significant for the local economy and development. However, if we look forward a little bit, we can know that China's aid, trade, and investment support are sectarian and do not cover all the 54 African countries. China-Africa should continue their excellent relationship and focus on the trust-trust policy to build a new area of aid, economic, investment, trade, and social relationships for a better future.

\section{Case of Central African Republic}

\subsection{Impact of China's Aid and Investment in Central African Republic}

China's aid and development finance to the Central African Republic are welcomed because it represents a strong benefit and encourages positively the Central African Republic's government efforts by improving the governance for sustainable development and contribute to long-term economic growth through infrastructure projects and income creation for the population. China's aid and development financing fills a void and promotes the development of the Central African Republic. The Central African Republic has been recovering since 2016, China has responded positively to the priority needs of the Central African Re- 
public. China's financial aid includes industrial promotion, health, peace, and security. At the invitation of the president of the Central African Republic, the Chinese police training team of the Fujian Police Academy (Fujian Police Academy) arrived in Bangui in November 2018 to strengthen the capacity of the presidential guard. During the training period, Chinese coaches and their students had to face equipment shortage, power failure, mosquito bites, and eventually became friends.

Nevertheless, the cooperation between the Central African Republic and China has made significant progress in peace and security. In agriculture aspect, China has promoted agricultural development, and the Chinese and Central African citizens are the first beneficiaries because Chinese government lead by President Xi Jinping did not hesitate to send a team of Chinese researchers to the Central African Republic to impart agricultural technology knowledge free of charge to Central African farmers.

However, the Chinese government continues to help the Central African Republic by building a solar panel farm, which was laid by the Central African Republic president on January 18, 2020. The project is located in Sakai in the west of Bangui, the Central African Republic's capital, with a production capacity of $15 \mathrm{MW}$. The project supports the country's electricity production, which is essential to get rid of the socioeconomic crisis. The Chinese enterprise Chang Jiang Institute of survey, planning, design, and Research Co., Ltd., the project contributed while helping solve its traditional hydropower and thermal production problems.

In sum, all the Chinese aid and investment contributed positively to the Central African Republic's economy and development this recent five years, and China continues to invest there. Nevertheless, this practice is problematic because many of the natural resource in Central African Republic which China works also suffers from severe political problems, such as authoritarianism, poor governance, and corruption.

\subsection{Impact Aid Projects Funded by China on the Economy and Development in the Central African Republic}

It is a question of creating a friendly environment between the inhabitants of Bangui and nearby municipalities, and the occasional visitors in a municipality where the associative fabric is strong but where infrastructures municipal and convenience stores do not enough and needs of the rapidly expanding demographic population. This territorial project has for vocation to develop the city's economic dynamism by creating a business and putting in the synergy of the local initiatives of general interest to favor the initiatives collective citizens, the social and inter-generational link of collaborative projects. China also focuses on education, the environment, citizenship, health, culture, and food in the population's service.

These projects have for objective to realize the upgrade of the Sino-Central African Republic bilateral or aid relationship. The projects concern below: 


\subsubsection{Medical Aid Assistant}

Nearly in 1980, and we can see in Photo 1, the Chinese government decided and built a friendship hospital under the bilateral relationship. This hospital contributed to the local economic development and the Central African region by saving people's lives. Recently, the Chinese government agreed to restore this hospital that was unpleasant and dirty. The Chinese government will support all it is under the bilateral relationship between the Central African Republic and China and the rehabilitation cost. Additionally in Photo 2, the hospital mother Domitien, the first lady's name, became a premier minister under Emperor Jean-Bedel BOKASSA's regime in 1975. Because of the problem with health facilities in the Central African Republic, the Chinese government has decided and built a new modern hospital to help the Central Africa Republic, especially Bimbo local citizens. The hospital covers a different department as a Pediatric, gynecology obstetric, intern medical, emergency, laboratories and XR medical. It is showed the real friendship cooperation between Sino-Centrafricano and contributing positively to the local population by creating a new job healthy environment.

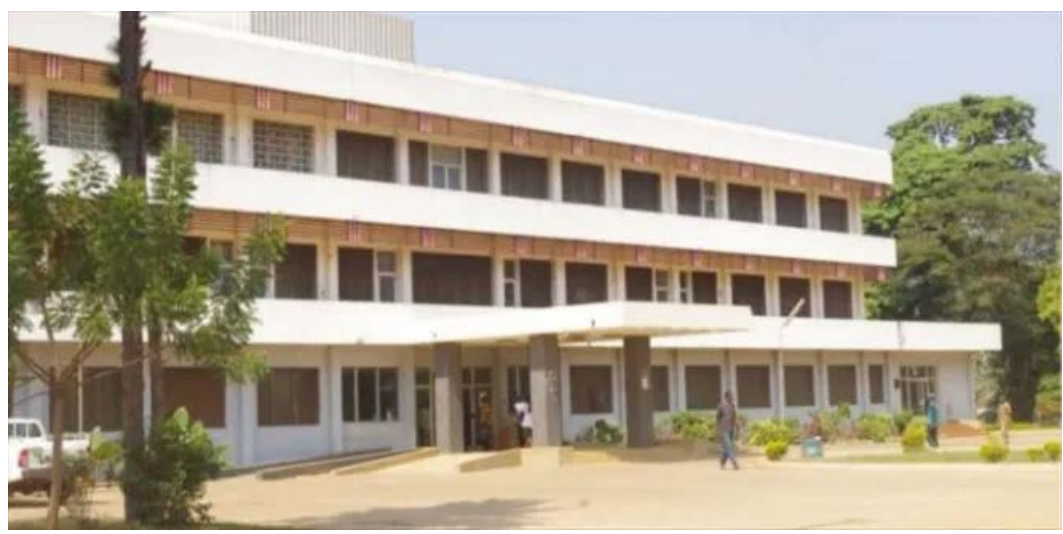

Photo 1. Friendship hospital. Source: Central African Republic government official site.

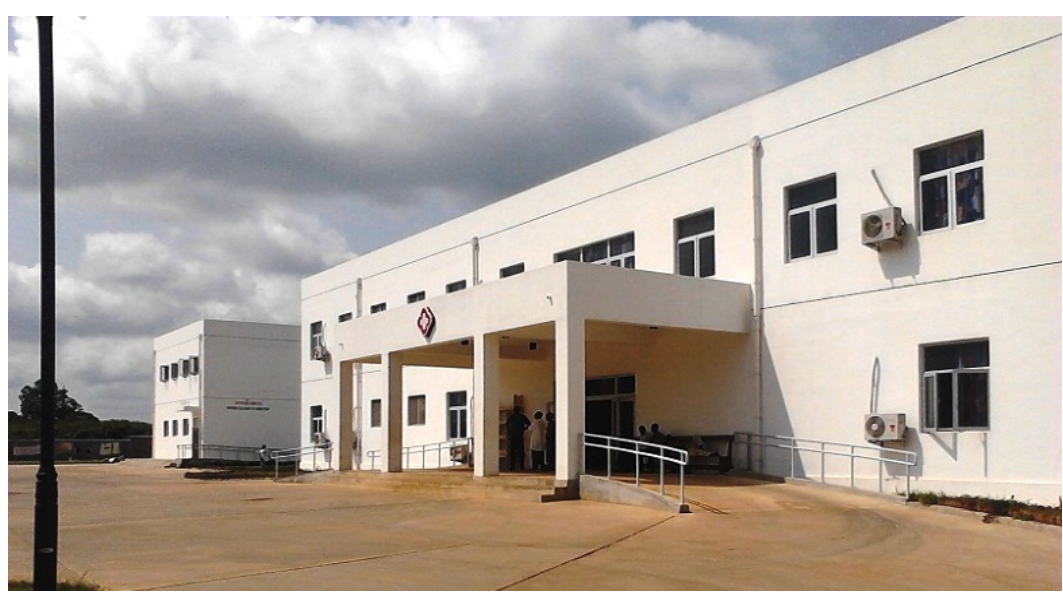

Photo 2. Hospital mother Domitien. Source: Central African Republic government official site. 


\subsubsection{Education Aid Assistance}

In terms of education that we can see in Photos 3-5, China has its existence in the Central African Republic. The friendship primary school calls in French "Ecole d'Excellence Chine-Centrafrique" was built and financing by the Chinese government from 1988 till now. Furthermore, the school has all support from China. The school educated most of the kids from 6 to 12 years old. According to the school principal's principal, the school office and students' supplies are all in China's charge. School principals even were to China for training to get a better guide for students. In this regard, the Central African Republic government has established a college to continue training students.

Nevertheless, the college is funded by the government of the Central African Republic. Besides, the Confucius Institute was established within China-Africa cooperation and started its academic activities at Bangui University on November 16th, 2020. The institute's mission is to teach and organize Chinese examinations, train local Chinese teachers, and initiate and even develop academic exchanges between Bangui University and Chinese universities. The school and the Confucius institute have made positive contributions to the Central African Republic education system, reducing the unemployment rate and raising the minimum wage. The Chinese government also allowed scholarships for the Central African Republic, who passed all their high school degree, to come and continue university in China. The same is to the internship students.

\subsubsection{Infrastructure Aid Assistance}

According to the bilateral cooperation between the Central African Republic and China, the Chinese government agreed to build Bangui's first biggest sports center in 2003. It takes the entire sphere as an international stadium and can hold 20000 people (Photo 6). Furthermore, Central African citizens appreciate the stadium. Besides, after seven years, when this bridge was destroyed, the Central African Republic government, due to lack of funds, could not restore the bridge that is the unique way for the Bimbo population to reach the town city for working or shopping. As China-Central Africa Republic bilateral relationship is in perfect attention, the Chinese government decided to repair this bridge. The bridge project was funded by the Ministry of Commerce of the People's Republic of China. The Shanxi construction engineering company group of China won the bridge control market from December 1st, 2016, to January 31st, 2018. It can use for 100 years, and it will help the circulation between the citizens (Photo 7). Also, it should be recalled that although the crisis persisted in the Central Africa Republic in 2013-2015, China remains and supports few projects such as the rehabilitation of administration buildings, Cite Christophe buildings, bimbo market, and the BOGANDA monument. (China Ministry of Foreign Affairs, China's Embassy in the Central African Republic and Central African Republic Ministry Finance and Budget and Ministry Planning and Economy). Indeed, this infrastructure aids assistance contributed to the local economic growth and development, beautified the city, and restored old buildings and the historical monu- 
ment. It helps the population feel convenient about the sport and when they want to move around the city.

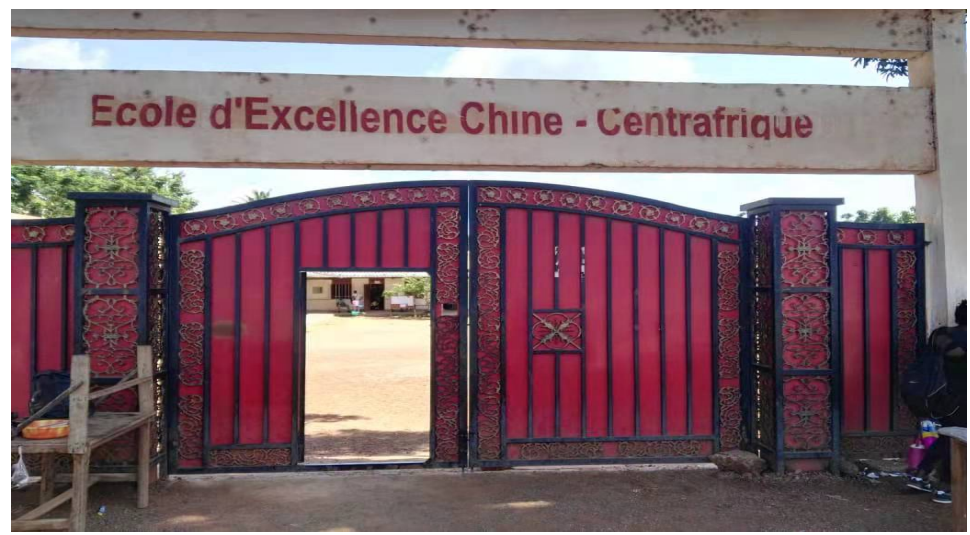

Photo 3. Friendship primary school. Source: Central African Republic government official site.

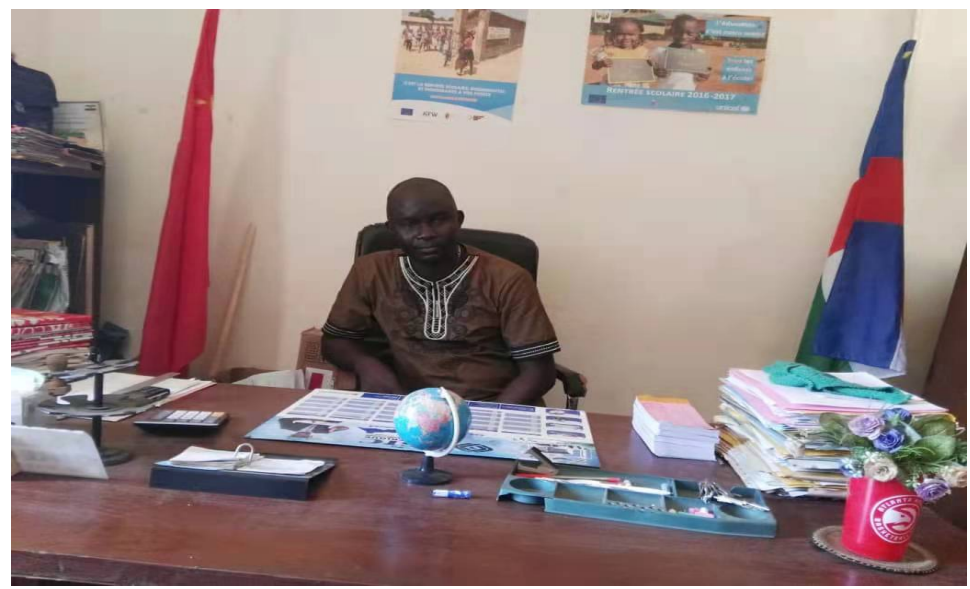

Photo 4. Friendship primary school acting principal. Source: Central African Republic government official site.

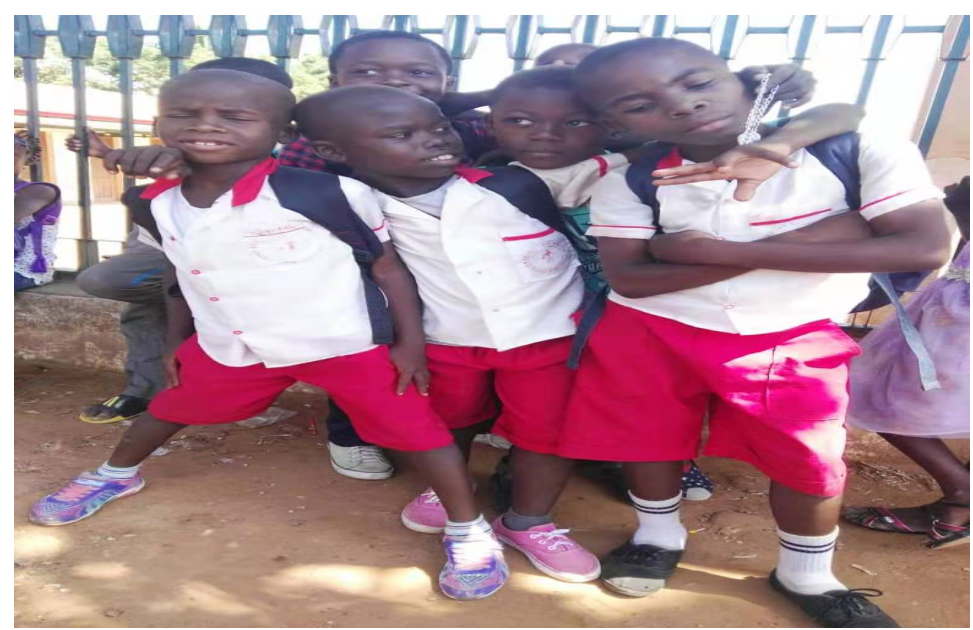

Photo 5. Friendship primary school students. Source: Central African Republic government official site. 


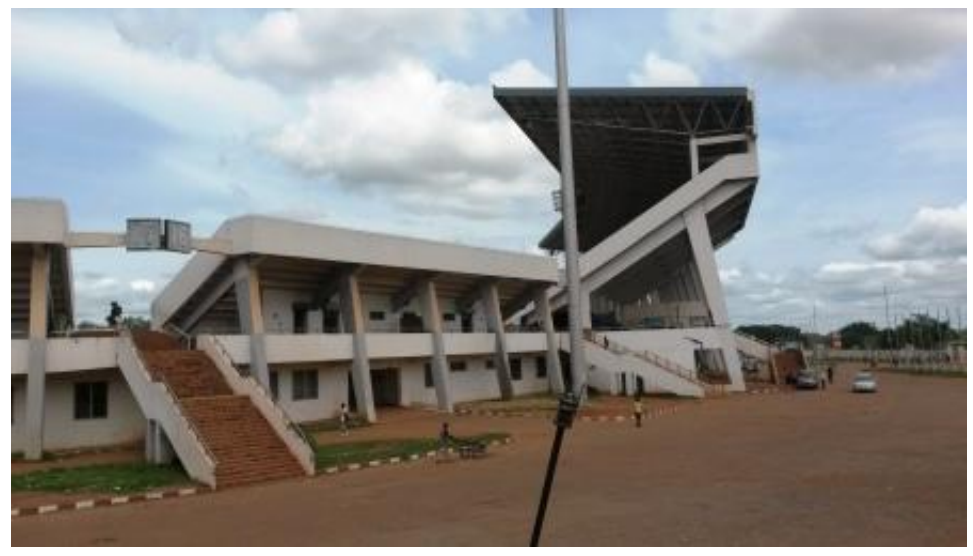

Photo 6. Stadium. Source: Central African Republic government official site.

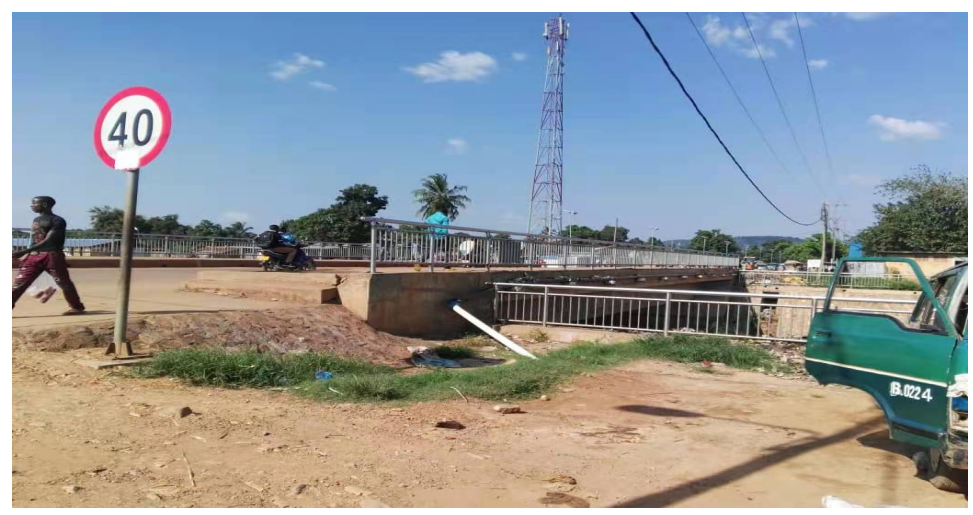

Photo 7. Sapeke Bridge. Source: Central African Republic government official site.

\section{Conclusion}

China's public investment policy in Africa continues to keep a good relationship, whether successful or unsuccessful. This new perspective is being opened for Chinese public investment in Africa and the Central Africa Republic as a part of it. In order to increase Chinese investment in the country, the Chinese government invested mostly in different sectors. The creation of a new policy in public aid will be carried out, particularly in the domestic and international markets. However, Chinese investors have confronted enormous challenges in Africa due to the cultural differences between Chinese and Africans, including the language barriers, often social tensions, and the insufficiency of infrastructures. Concerning the case of the Central African Republic harms in companies' functioning, the breakdowns frequented by electricity increase production costs, and political policies to companies are ill-assorted. The internal conflicts raise severe problems for the Chinese companies to work typically. Some government officials do not respect the policies and cause trouble for these companies (corruption). However, most of the African countries' economic growth situation are unstable particularly the case of the Central Africa Republic government's economic situation. Thus, both parties should find another perspective to solve this issue by 
making rigorous policies.

\section{Ethical Approval}

No ethical approval was required for this study. The study explored public data.

\section{Conflicts of Interest}

The authors declare no conflicts of interest regarding the publication of this paper.

\section{References}

Annen, K. (2003). Social Capital, Inclusive Networks, and Economic Performance. Journal of Economic Behavior and Organization, 50, 449-463. https://doi.org/10.1016/S0167-2681(02)00035-5

Bohoslavsky, J. P. (2016). Economic Inequality, Debt Crises and Human Rights. The Yale Journal of International Law Online, 41, 177-199.

Brautigam, D. (2009). Chapter 7: Flying Geese, Crouching Tiger: China's Changing Role in African Industrialization. In D. Brautigam Ed., The Dragon's Gift-The Real Story of China in Africa (pp. 189-210). New York: Oxford University Press.

Busse, M., \& Gröning, S. (2013). The Resource Curse Revisited: Governance and Natural Resources. Public Choice, 154, 1-20. https://doi.org/10.1007/s11127-011-9804-0

Carmignani, F., \& Chowdhury, A. (2012). The Geographical Dimension of the Development Effects of Natural Resources. Environmental and Resource Economics, 52, 479-498. https://doi.org/10.1007/s10640-011-9539-X

OECD, AFDB, UNDP \& ECA (2013). African Economic Outlook 2013. Paris: Organisation for Economic Co-Operation and Development.

Hwang, Y. H., Kim, Y. W., Kang, D. H., Kim, Y.S., \& Liebeskind, D. S. (2016). Impact of Target Arterial Residual Stenosis on Outcome after Endovascular Revascularization. Stroke, 47, 1850-1857. https://doi.org/10.1161/STROKEAHA.116.013046

Kolstad, I., \& Wiig, A. (2011). Better the Devil You Know? Chinese Foreign Direct Investment in Africa. Journal of African Business, 12, 31-50. https://doi.org/10.1080/1536710X.2011.555259

Lakatos, A. (2016). The Frozen Conflict of the Black Garden. Geopolitical, Geo-Economic Implications of the Conflicts from Nagorno Karabah, in Geopolitical, nr. 64-65. 255-262.

Lin, Z. H., Luo, X. L., \& Yu, H.T. (2016) Structural Basis of Cohesion Cleavage by Separase. Nature, 532, 131-134. https://doi.org/10.1038/nature17402

Liu, H. W., \& Lu, L.Y. (2013). Chinese Dream and African Dream: The Construction of China-Africa Community with a Shared Future. West Asia and Africa, No. 6, 19-33.

Morrissey, O., \& Zgovu, E. (2011) The Impact of China and India on Sub-Saharan Africa: Opportunities, Challenges and Policies. London: Commonwealth Secretariat.

Sautman, B., \& Yan, H. R. (2009). African Perspectives on China-Africa Links. The China Quarterly, 199, 728-759. https://doi.org/10.1017/S030574100999018X

Shambaugh, D. (2015). China's Soft Power Push: The Search for Respect. Foreign Affairs, 94, 99-107.

$\mathrm{Su}, \mathrm{H}$. (2017). Community of Shared Future, International Public Goods and Institutional Voice the Angle between China and the United States on China's Investment. Africa 
Journal of Regional and Global Development, 1, 113-126, 158-159.

Sun, W. (2014). Development and Changes of China-Africa Economic Cooperation in the New Century. International Economic Cooperation, No. 9, 36-39.

UN Comtrade (2014) United Nations Commodity Trade Statistics Database. SITC Rev. 3. http://comtrade.un.org/

UNCTAD (2013) World Investment Report 2013. New York and Geneva: United Nations.

World Bank (2014) World Development Indicators.

https://datahelpdesk.worldbank.org/knowledgebase/articles/906522-data-upda tes-and-errata

Zhang, H.H. (2016). China-Africa Mutual Cooperation with African Resources Development and Utilization Fate. Journal of World Economics and Politics BBS, No. 3, 169-172.

Zhang, J. (2017). The Evolution of China's One-Child Policy and Its Effects on Family Outcomes. Journal of Economic Perspectives, 31, 141-160.

https://doi.org/10.1257/jep.31.1.141

\section{Archives}

Central Africa: Economic collapse. Radio France Internationale (Archives).

Decision of the Central Committee of the Communist Party of China on several major issues concerning comprehensively deepening the reform, November 15, 2013. (Archives).

Ministry of Planning and Economy (Archives).

Silent Death in Central Africa, Vincent Munia, Foreign Monde, October 2013 (Archives).

J. Soupou/ACAP, "Signing of Bangui Friendship Hospital Rehabilitation Contract” (Archives). China and Africa News Agency reported. Bangui, Central African Republic (Archives). 